\title{
Análise crítica à modulação dos efeitos em decisão de inconstitucionalidade de matéria tributária
}

\author{
Critical analysis to the modulation of temporal effects in decisions of unconstitutionality in \\ taxation law
}

\author{
Paola Maria Gallina ${ }^{1}$ \\ Profa. Dra., Marlene Kempfer Bassoli ${ }^{2}$
}

\begin{abstract}
Resumo
0 presente estudo irá discorrer acerca da modulação dos efeitos temporais em decisões que declaram inconstitucional a norma tributária. Tratar-se-á sobre 0 controle de constitucionalidade, bem como sobre a repetição do indébito. Analisarse-á 0 artigo 27 da Lei no. 9.868/1999, o qual conferiu ao Supremo Tribunal Federal o poder de modular os efeitos temporais das decisões de inconstitucionalidade, observando os seus reflexos no to cante à repetição do indébito tributário.
\end{abstract}

Palavras Chave: Inconstitucionalidade do Tributo; Repetição de Indébito; Modulação de Efeitos Temporais.

Abstract

The present study will discourse about the modulation of temporal effects in the decisions that declare unconstitutional a tax law. It will also deal with the constitutional control, as well as the restoration of undue payments. The article 27 of the Law no. 9.868/1999 will be analyzed, which conferred to the Supreme Federal Court the power of modulating the secular effect of the unconstitutionality decisions, observing their effects on restoration of undue payments of tax.

Keywords: Unconstitutionality of Tax; Restoration of Undue Payments; M odulation of Temporal Effects.

\section{Introdução}

Atualmente tem se verificado um grande número de julgados acerca da constitucionalidade de matérias de conteúdo tributário. Tal fato se dá em razão de o Sistema Tributário Nacional encontrar-se disposto de maneira detalhada no texto constitucional,

\footnotetext{
${ }^{1}$ Discente do 50 ano do Curso de Direito da Universidade Estadual de Londrina.

${ }^{2}$ Doutora em Direito do Estado - Direito Tributário pela PUC-SP. Docente de Direito Tributário na graduação do Curso de Direito da Universidade Estadual de Londrina e dos programas de Mestrado em Direito da Universidade Estadual de Londrina e da Universidade de Marília.
} 
viabilizando a possibilidade de frequentes ofensas a estas normas de estrutura no momento do processo de positivação.

0 posto de guardião da Constituição é do Supremo Tribunal Federal, que fiscaliza se as normas infraconstitucionais estão em consonância com a Carta Magna.

A declaração de inconstitucionalidade de um tributo ou mesmo de uma norma relacionada à matéria tributária pode gerar o dever do Estado de devolver àquilo que foi pago pelos contribuintes a título de tributo indevido. A questão que se pretende analisar diz respeito aos efeitos temporais que podem ser atribuídos a estas decisões face ao disposto no Art. 27 da Lei no 9868/99.

Ao contribuinte credor de tributos é difícil compreender as justificativas do Supremo Tribunal Federal quando decide pelo efeito "ex nunc" de suas decisões, uma vez que isto significa, na prática, o reconhecimento de que a devolução da prestação pecuniária paga não ocorrerá, uma vez que os efeitos desta decisão valem para o futuro. Os fundamentos nos termos legais devem ser razões de segurança jurídica ou de excepcional interesse social, tornando-se ainda mais necessária a discussão face à indeterminação destes termos, especialmente, do que seja "excepcional interesse social".

\section{Controle de constitucionalidade}

Para melhor compreender o sistema jurídico deve se ter em vista a ideia piramidal de ordenamento ditada por Kelsen (apud CARRAZAA, 2007, p. 33). A pirâmide jurídica está constituída de modo que as normas inferiores encontram-se mais para a sua base, enquanto que as superiores são encontradas mais para o topo da pirâmide.

De acordo com Kelsen (apud CARRAZA, 2007, p. 34) as normas inferiores buscam validade nas normas superiores de forma a se harmonizarem entre si. Em se tratando de "normas de hierarquia diversa, prevalecerá a superior, isto é, a de mais alta hierarquia, porque à outra, exatamente por contraditá-la, faltará validade".

0 ordenamento jurídico preconiza pela existência de normas harmônicas e compatíveis entre si, diante disto, é imperiosa a realização de um controle de compatibilidade das normas jurídicas infraconstitucionais face à Constituição Federal. 
A necessidade de fiscalizar a harmonia entre as normas constitucionais e as infraconstitucionais tem embasamento na Supremacia da Constituição, a qual preleciona que não há no ordenamento jurídico norma superior à Constituição Federal.

Consoante 0 entendimento dos doutrinadores Luís Roberto Barroso (2008, p. 1-2) e Paulo Bonavides (2008, p. 196-297), a rigidez constitucional também é um fundamento do controle de constitucionalidade, já que, em face da norma constitucional ter um processo de elaboração mais severo do que as infraconstitucionais, existe uma distinção formal entre elas.

A primeira manifestação do controle de constitucionalidade remonta do início do século XIX, mais especificamente no ano de 1803, nos Estados Unidos por meio do célebre julgamento do caso Marbury v. Madison, relatado por John Marshall. A Suprema Corte norte-americana, firmando-se como poder superior a todos os poderes constituídos, declarou a inconstitucionalidade de uma lei, exercendo o controle de constitucionalidade no caso concreto (BARROSO, 2008, p. 5).

Assim, pode-se afirmar que a falta de compatibilidade e harmonia das normas infraconstitucionais com a Constituição gera o fenômeno da inconstitucionalidade.

Efeitos da declaração de inconstitucionalidade da norma

Para se verificar os efeitos da declaração de inconstitucionalidade é imperiosa a análise das teorias da anulabilidade e nulidade da norma inconstitucional.

Com base em ensinamentos do filósofo Hans Kelsen (apud GRECO; PONTES, 2002, p.14), a teoria da anulabilidade da norma inconstitucional surgiu em 1920 na Áustria. Para o estudioso, a lei inconstitucional era válida até a decisão que proferisse a sua inconstitucionalidade. Assim, a lei inconstitucional era anulável, sendo certo que a decisão que a pronunciava tinha caráter constitutiva negativa, produzindo-se apenas efeitos ex nunc.

No Brasil, defenderam a tese da anulabilidade, entre outros, os doutrinadores Pontes de M iranda e Regina Macedo Nery Ferrari ${ }^{3}$, bem como o Ministro Leitão de Abreu, entretanto, esta tese não ganhou força neste ordenamento.

\footnotetext{
${ }^{3}$ A norma constitucional é simplesmente anulável, visto que esta qualidade lhe é imposta por um órgão competente, conforme o ordenamento jurídico, e que opera, eficaz e normalmente, como qualquer disposição normativa válida até a decretação de sua inconstitucionalidade. Em decorrência disso, a sentença que declara a inconstitucionalidade é do tipo constitutiva (FERRARI, 2004, p. 275).
} 
Se por um lado a teoria da anulabilidade não teve impacto no Brasil, a teoria da nulidade obteve adesão expressiva, tendo sido reconhecida pelo Supremo Tribunal Federal:

[...] Atos inconstitucionais são, por isso mesmo, nulos e destituídos, em consequência, de qualquer carga de eficácia jurídica.

A declaração de inconstitucionalidade de uma lei alcança, inclusive, os atos pretéritos com base nela praticados, eis que o reconhecimento desse supremo vício jurídico, que inquina de total nulidade os atos emanados do poder público, desampara as situações constituídas sob sua Égide e inibe - ante a sua inaptidão para produzir efeitos jurídicos válidos - a possibilidade de invocação de qualquer direito (STF, 1993, p. 5615).

A tese da nulidade preleciona que a lei inconstitucional é nula de pleno direito. A decisão que declara a inconstitucionalidade da lei é declaratória, produzindo efeitos ex tunc, os quais retroagem ao momento do nascimento da lei.

A teoria da nulidade adotada no Brasil não é absoluta, pois comporta exceções, entre as quais o artigo 27 da lei no. 9.868/1999, o qual confere ao Supremo Tribunal Federal o poder de modular os efeitos temporais das decisões que declaram inconstitucionais leis ou atos normativos, possibilitando-se que a decisão de inconstitucionalidade adquira apenas efeitos prospectivos.

Controle de constitucionalidade da norma impositiva tributária

o Controle de Constitucionalidade em matéria tributária, bem como os efeitos da declaração de inconstitucionalidade desta, ocorre tal como demonstrado anteriormente, acrescido de algumas especificidades. Estas são inerentes à própria disciplina do direito tributário, as quais em seguida serão analisadas.

A Constituição Federal tratou de maneira pormenorizada a matéria tributária, de modo que delineou todo o Sistema Tributário Nacional, ditando as suas regras de estrutura e os seus princípios, os quais apontam como a norma impositiva deverá ser editada, modificada ou extinta.

0 exame de constitucionalidade das normas tributárias deverá constatar se estas se encontram em consonância com os princípios da legalidade (inciso I do artigo 150 da Constituição Federal ${ }^{4}$ ), da irretroatividade da norma tributária, da anterioridade e da

\footnotetext{
4 “[...] é vedado à União, aos Estados, ao Distrito Federal e aos Municípios: I - exigir ou aumentar tributo sem lei que o estabeleça". (destacou-se).
} 
noventena (alíneas a, b e c do inciso III do artigo 150 da Constituição ${ }^{5}$ ), bem como se seguiram as regras estruturais da Constituição, como por exemplo, a observância das competências tributárias distribuídas pelos artigos 153, 155 e 156 da Constituição Federal, bem como o respeito ao regime jurídico de cada espécie tributária disciplinada pela Carta Magna.

Uma vez constatada que a norma impositiva tributária é incompatível com os princípios e regras estruturais citadas alhures, argumenta-se que esta se encontra acometida pelo vício da inconstitucionalidade, sendo considerada nula ab initio.

Portanto, se for verificada que a norma instituidora o tributo era inconstitucional, entende-se que este nunca deveria ter sido exigido do contribuinte, assim como não poderia ter sido arrecadado pelo Estado, vez que os efeitos da pronúncia de inconstitucionalidade são ex tunc, ou seja, retroagem desde a edição da lei.

\section{Repetição do indébito diante da declaração de inconstitucionalidade da norma tributária}

A declaração de inconstitucionalidade da norma tributária faz com que o Estado tenha o dever de restituir o tributo recolhido pelo contribuinte. A devolução da importância paga deve ser pleiteada através da ação de repetição do indébito em nível administrativo ou jurisdicional.

A repetição do indébito fundamenta-se no reconhecimento de que o pagamento do tributo declarado incompatível com a Constituição é considerado indevido. A fim de que o tributo seja indevido, bem como para que nasça a obrigação do Estado de devolver a espécie tributária declarada inconstitucional, deve a eficácia da decisão de inconstitucionalidade ser ex tunc, de modo que seus efeitos retroajam à data da entrada em vigor da norma.

Para Paulo Roberto Lyrio Pimenta (2002, p. 122-123) repetição do indébito:

É uma relação jurídica, por força da qual o Fisco fica adstrito a devolver ao sujeito passivo da obrigação tributária o tributo indevido. A relação surge do simples pagamento indevido [...].

\footnotetext{
5 “[... ] é vedado à União, aos Estados, ao Distrito Federal e aos M unicípios: III - cobrar tributos: a) em relação a fatos geradores ocorridos antes do início da vigência da lei que os houver instituído ou aumentado; b) no mesmo exercício financeiro em que haja sido publicada a lei que os instituiu ou aumentou; c) antes de decorridos noventa dias da data em que haja sido publicada a lei que os instituiu ou aumentou, observado 0 disposto na alínea b" (destacou-se).
} 
Embora a repetição do indébito esteja regulamentada pelo artigo 165 do Código Tributário Nacional, parte da doutrina ${ }^{6}$ tem entendido que este não deve ser aplicado em caso de inconstitucionalidade do tributo.

Defendem que a hipótese da inconstitucionalidade do tributo não pode ser enquadrada em nenhum dos incisos do artigo 165 do Código Tributário Nacional, até porque, estes discorrem somente sobre equívoco na aplicação da legislação válida e aplicável, nada versando acerca da devolução do indébito em face de declaração de invalidade da norma tributária.

Ao revés, o doutrinador Aliomar Baleeiro (1998, p. 881), entende que "os tributos resultantes de inconstitucionalidade, ou de ato ilegal, são os casos mais frequentes do inciso I do art. 165".

Divergindo do entendimento supra esposado, o referido doutrinador argumenta que a hipótese de inconstitucionalidade seria regida pelo regime do Código Tributário Nacional, vez que esta estaria disposta pelo inciso I.

Pelo que se viu, não há consenso entre a doutrina quanto à aplicabilidade do Código Tributário Nacional com relação à repetição do indébito de tributo declarado inconstitucional.

Aqueles que entendem que 0 referido Codex não é aplicável à hipótese de inconstitucionalidade apresentam de maneira bem fundamentada os princípios que autorizam a repetição do indébito, princípios estes que serão demonstrados no tópico seguinte.

Princípios que autorizam a repetição do indébito de tributo inconstitucional

O doutrinador Paulo Lyrio Pimenta (2002, p. 126) afirma que a devolução do tributo declarado inconstitucional está assegurada pelos princípios constitucionais da legalidade, da moralidade, da boa-fé, da nulidade da norma inconstitucional e da proibição do enriquecimento sem causa.

A repetição do indébito se embasa no princípio da legalidade, já que a elaboração da norma tributária deve estar adstrita aos aspectos formais e materiais ditados pela

\footnotetext{
${ }^{6}$ Os autores Paulo Lyrio Pimenta, Helenilson Cunha Pontes, Marco Aurélio Greco, Domingos Franciulli Netto e Antonio Roberto Sampaio Dória.
} 
Constituição Federal. Se não forem observados tais ditames o Estado "não pode fazer jus à percepção do quantum arrecadado com base num fato ilícito" (PIM ENTA, 2002, p. 126).

No que tange aos princípios da moralidade e da boa-fé, vale dizer que não pode 0 Estado se apropriar dos tributos inconstitucionais recolhidos, posto que isto viola os princípios éticos da sociedade.

O princípio da nulidade da norma inconstitucional determina que a pronúncia de invalidade deva ter eficácia ex tunc, a fim de que a decisão seja retroativa e atinja 0 pagamento do tributo realizado pelo contribuinte, tornando-o inválido e passível de ressarcimento pelo Estado, já que é imprescindível à recomposição do contribuinte ao status quo ante.

Ademais, não deve 0 Estado reter os valores recebidos a título de tributo inconstitucional (indevidos), já que estará enriquecendo ilicitamente à custa do empobrecimento do contribuinte.

A declaração de inconstitucionalidade da norma tributária com efeitos ex tunc gera o dever do Estado de restituir o tributo indevido. Seja por autorização do Código Tributário Nacional (artigo 165, inciso I) ou ainda pelos princípios supracitados, observou-se que a repetição do tributo inconstitucional é perfeitamente possível no ordenamento jurídico brasileiro.

\section{Análise do artigo 27 da lei no. 9.868/1999 ante da declaração de inconstitucionalidade em matéria tributária}

Por meio da lei ำ. 9.868/1999 foram introduzidas várias inovações nas ações do controle concentrado de constitucionalidade. 0 artigo 27 foi uma dessas inovações, permitindo a limitação dos efeitos de decisão de inconstitucionalidade pelo Supremo Tribunal Federal, nos seguintes termos:

Ao declarar a inconstitucionalidade de lei ou ato normativo, e tendo em vista razões de segurança jurídica ou de excepcional interesse social, poderá o Supremo Tribunal Federal, por maioria de dois terços de seus membros, restringir os efeitos daquela declaração ou decidir que ela só tenha eficácia a partir de seu trânsito em julgado ou de outro momento que venha a ser fixado.

0 citado dispositivo inspirou-se no modelo português, o qual conferiu ao Tribunal 
Constitucional lusitano o poder de restringir os efeitos da decisão de inconstitucionalidade, quando presentes segurança jurídica, razões de equidade ou interesse público de excepcional relevo (artigo 282, n. 4 da Constituição Portuguesa ${ }^{7}$ ).

A modulação dos efeitos temporais é uma forma de atenuação à teoria da nulidade do ato inconstitucional adotada pelo Brasil, pois impede a adoção de eficácia retroativa das decisões de inconstitucionalidade, admitindo-se que uma norma inconstitucional seja válida e eficaz até a sua declaração de incompatibilidade com a Constituição ou mesmo a partir de outro momento estabelecido pelo Supremo Tribunal Federal.

Embora tenha havido esta moderação, a regra ainda continua sendo a nulidade da norma inconstitucional, sendo que a limitação dos efeitos retroativos da lei só pode ocorrer em casos excepcionais, desde que presentes os requisitos ditados pelo artigo 27 da referida lei.

\section{Requisitos para a modulação de efeitos temporais}

Os efeitos temporais das decisões de inconstitucionalidade são, em regra, ex tunc. 0 Supremo Tribunal Federal possui a prerrogativa de modular estes efeitos, encontrando-se esta limitação adstrita a certos requisitos estabelecidos em lei.

Alexandre de Moraes (2008, p. 756-757) pondera que para a manipulação dos efeitos temporais da pronúncia de inconstitucionalidade devem ser preenchidos dois requisitos constitucionais, os quais são divididos em formais e materiais, sendo certo que aquele diz respeito ao quórum de maioria de dois terços dos ministros do Supremo Tribunal Federal e este discorre acerca da presença de razões de segurança jurídica ou de excepcional interesse social.

Preenchidos os mencionados requisitos formais e materiais, a Corte Suprema do Brasil poderá fixar a produção de efeitos a partir do trânsito em julgado da decisão de inconstitucionalidade em controle concentrado ou, ainda, a partir de qualquer outro momento que venha a ser fixado.

Deverão ser fortes e concretas as razões de segurança jurídica e interesse social,

\footnotetext{
${ }^{7}$ Quando a segurança jurídica, razões de equidade ou interesse público de excepcional relevo, que deverá ser fundamentado, o exigirem, poderá o Tribunal Constitucional fixar os efeitos da inconstitucionalidade ou da ilegalidade com alcance mais restrito do que o previsto nos n. 1 e 2. (destacou-se)
} 
uma vez que admitir a fixação de efeitos ex nunc e a produção de efeitos pro futuro de norma declarada inconstitucional é aceitar que àquelas razões se sobreponham e sejam consideradas mais importantes que a própria Constituição, norma que está no ápice da pirâmide jurídica.

\section{Segurança Jurídica e Excepcional Interesse Social}

A modulação dos efeitos exige uma justificativa do órgão constitucional. Como justificativa deverá ser demonstrado que, no caso hipotético, a retroatividade da decisão de inconstitucionalidade seria tão maléfica, de forma que o princípio da segurança jurídica ou do excepcional interesse social devesse se sobrepor ao princípio da nulidade da norma inconstitucional, a fim de resguardar a paz social ou ainda outro valor de excepcional interesse da coletividade.

Extrai-se que para a aplicação do artigo 27 da lei no. 9.868/1999 deverá ser sopesado o princípio da nulidade da norma inconstitucional - de um lado - e os postulados da segurança jurídica ou interesse social - de outro (MARTINS; M ENDES, 2007, p. 419).

0 princípio da proporcionalidade é que irá auxiliar a resolver tal controvérsia, sendo certo que por meio de um juízo de ponderação verificar-se-á qual valor tem mais relevância, bem como qual melhor se encaixa ao caso concreto.

Quando se fala em modulação de efeitos, a celeuma reside na dificuldade em delimitar os conceitos de segurança jurídica e excepcional interesse social.

Consoante Ricardo Lobo Torres (2005, p. 74-76) "segurança jurídica é certeza e garantia dos direitos. É a paz.". O princípio da segurança jurídica encontra-se no bojo do artigo 50 da Constituição Federal ${ }^{8}$, sendo certo que este tem por fim precípuo afastar a insegurança, "fazendo com que as pessoas possam prever, com relativa certeza, as consequências que advirão das situações jurídicas a que deram causa" (CARRAZA, 2007, p. 426).

$\mathrm{Na}$ esfera tributária a segurança jurídica se relaciona com os princípios da legalidade e da tipicidade, uma vez que os tributos devem estar minuciosamente dispostos em lei "de

\footnotetext{
8 "Todos são iguais perante a lei, sem distinção de qualquer natureza, garantindo-se aos brasileiros e aos estrangeiros residentes no País a inviolabilidade do direito à vida, à liberdade, à igualdade, à segurança e à propriedade, nos termos seguintes." (destacou-se).
} 
modo tão preciso e determinado, que 0 aplicador não tenha como introduzir critérios subjetivos de apreciação, que poderiam afetar, [...], a segurança jurídica dos contribuintes, comprometendo-lhes a capacidade de previsão objetiva de seus direitos e deveres" (CARRAZZA, 2007, p. 429).

Ocorre que a segurança jurídica citada pelo artigo 27 da lei o 9.868/1999, quando se tem em vista matéria tributária, não diz respeito à analisada anteriormente, mas se refere àquela ligada à perda de arrecadação do Estado. Neste contexto, com vistas a evitar "problemas de caixa" (CARRAZA, 2007, p. 483), isto é, grande instabilidade financeira ao Estado, é que o citado dispositivo permite que seja afastado o princípio da nulidade da norma inconstitucional.

0 termo interesse social, do mesmo modo, está acobertado de subjetivismo, encontrando-se intimamente ligado à ideia de bem comum.

De acordo com a melhor doutrina ${ }^{9}$ há distinção entre o interesse público primário e o interesse público secundário.

O interesse público primário, isto é, interesse verdadeiramente público é "aquele que pertence à coletividade, independentemente do interesse eventualmente diverso da entidade pública" (MEDINA apud BIM, 2005, p. 54), ao passo que, o interesse público secundário diz respeito aos anseios do Estado, ou seja, seus interesses particulares.

Transportando o conceito de interesse público secundário para campo do direito tributário convém destacar que, nesta seara, muitas vezes confunde-se interesse fazendário (meramente arrecadatório) com interesse público.

0 doutrinador Roque Antonio Carrazza (2007, p. 483) alerta que 0 interesse arrecadatório "subordina-se ao interesse público e, por isso, só poderá prevalecer quando em perfeita sintonia com ele".

Em que pese pareça ter sido rechaçada a ideia do in dúbio pro fiscum, será demonstrado ao longo do estudo que geralmente as razões de segurança jurídica, bem como o relevante interesse social são utilizados como subterfúgios para dissimular as ações arbitrárias do Fisco frente ao contribuinte.

\footnotetext{
${ }^{9}$ Celso Antônio Bandeira de M ello, Fábio M edina Osório e Marçal Justen Filho.
} 


\section{Considerações acerca da constitucionalidade do artigo 27 da lei $n=9.9 .868 / 1999$}

A constitucionalidade do dispositivo legal que autorizou o Supremo Tribunal Federal a limitar os efeitos retroativos da decisão de inconstitucionalidade (artigo 27 da lei no 9.868/1999) tem sido muito discutida.

As ADIns no $2.154-2 / D F$ e 2.258-0/DF ${ }^{10}$ arguiram a inconstitucionalidade do artigo 27 da lei no 9.868/1999, sendo certo que a ADIn № 2.258-0/DF argumentou que 0 dispositivo fere o Estado Democrático de Direito, bem como o princípio da legalidade, além de afrontar a supremacia da Constituição Federal.

O estudioso Ives Gandra da Silva M artins, que fez parte da comissão do anteprojeto da lei no 9.868/1999, foi voto vencido, uma vez que foi totalmente contrário à modulação dos efeitos da decisão de inconstitucionalidade. Inconformado escreveu sobre o tema aduzindo que a limitação dos efeitos da decisão de inconstitucionalidade:

[...] nitidamente afronta a tradição do Direito brasileiro de que a norma ou é constitucional ou não o é.

Sendo dedicado a disciplinar a declaração final de inconstitucionalidade - [...] - 0 dispositivo fere o Direito brasileiro e a própria orientação da Suprema Corte de que ou as normas são constitucionais e tem eficácia, ou são inconstitucionais e não têm eficácia.

Se uma norma tiver sido afastada do cenário jurídico nacional pelo vício maior da inconstitucionalidade, não há como considerar seus efeitos válidos, como se constitucional fosse no passado ou - o que é pior - mantê-los com validade ainda por certo período de tempo, como ocorre no Direito germânico, de conformação diversa do Direito brasileiro. (MARTINS, 2001, p. 178-179).

Ainda que Paulo Roberto Lyrio Pimenta (2002, p. 99-100) seja favorável à manipulação dos efeitos da pronúncia de inconstitucionalidade por defender que esta se encontra implicitamente autorizada na Constituição Federal, 0 autor argumenta que 0 artigo 27 da lei no 9.868/1999 é inconstitucional e, de tal modo, não merece ser aplicado na fixação dos efeitos da declaração de inconstitucionalidade.

Para ele o controle de constitucionalidade das normas é uma forma do judiciário fiscalizar as atividades do legislativo. Assim, "não pode o poder controlado editar norma infraconstitucional restringindo, ou até mesmo ampliando a competência do órgão

\footnotetext{
${ }^{10}$ As referidas ADIns ainda se encontram pendentes de julgamento.
} 
controlador, no caso, o Poder Judiciário" (PIM ENTA, 2002, p. 99). Conclui afirmando que a competência para controlar o poder legislativo só pode ser alterada através de emenda à Constituição, carecendo de constitucionalidade à regulamentação realizada por meio de lei ordinária.

Do mesmo modo, o doutrinador Luís Roberto Barroso (2008, p. 24) apontou que a inconstitucionalidade do dispositivo é formal, vez que a modulação dos efeitos da pronúncia de inconstitucionalidade deveria ter sido introduzida por meio de emenda à Constituição e não lei ordinária.

A constitucionalidade do artigo 27 da lei no 9.868/1999 também é debatida quando se tem em vista a sua parte final, a qual permite que o Supremo Tribunal Federal fixe os efeitos da declaração de inconstitucionalidade em termo posterior à publicação da decisão.

0 doutrinador Alexandre de M oraes (2008, p. 758) não aceita a fixação dos efeitos prospectivos, isto é, em data posterior à decisão de inconstitucionalidade. Veja:

Se o STF entender pela aplicação dessa hipótese excepcional, deverá escolher como termo inicial da produção dos efeitos, qualquer momento entre a edição da norma e a publicação oficial da decisão. Desta forma, não poderá o STF estipular como termo inicial para a produção dos efeitos data posterior à publicação da decisão no Diário Oficial, uma vez que a norma inconstitucional não mais pertence ao ordenamento jurídico, não podendo permanecer produzindo efeitos.

Oswaldo Luiz Palu (2001, p. 178 e 186) também comunga de tal entendimento e argumenta ser inadmissível à permissão dada por lei infraconstitucional de se atribuir efeitos pro futuro à lei inconstitucional.

A autora Regina Maria Nery Ferrari (2004, p. 163) também nega a constitucionalidade do dispositivo, afirmando que não há como se aceitar que uma norma inferior, após a declaração de sua incompatibilidade com a Constituição, continue a existir e a produzir efeitos.

Como se viu, as críticas feitas ao artigo 27 da lei no 9.868/1999 no tocante à sua constitucionalidade são vastas e muito bem fundamentadas. 


\section{Limitação dos efeitos temporais em matéria tributária e seu reflexo na repetição do indébito}

A modulação dos efeitos da decisão de inconstitucionalidade gera algumas consequências para a repetição do indébito. Constata-se que tais consequências são claramente prejudiciais ao contribuinte que pagou corretamente o tributo posteriormente declarado inconstitucional.

Em que pese esse caráter de prejudicialidade, observa-se que a jurisprudência do Supremo Tribunal Federal tem caminhado para a adoção da restrição dos efeitos temporais em matéria tributária como regra, sem observar o seu caráter excepcional.

Conforme analisado, uma vez declarada a inconstitucionalidade do tributo, este deverá ser restituído ao contribuinte que o pagou. A restituição embasa-se no fato de que quando o tributo é declarado inconstitucional, este nunca deveria ter sido exigido do contribuinte, já que é inválido.

0 pagamento do tributo declarado inconstitucional é indevido, não podendo 0 Estado se apoderar do indébito, sob pena de ferir os princípios da legalidade, da moralidade, da boa-fé, da nulidade da norma inconstitucional e do enriquecimento sem causa (PIM ENTA, 2002, p. 126).

A manipulação dos efeitos temporais em matéria tributária atinge diretamente a restituição do tributo inconstitucional. Se os efeitos da decisão de inconstitucionalidade forem limitados para ex nunc, o que denota que a norma instituidora do tributo será inválida e terá sua vigência cessada somente a partir da decisão do Supremo, o contribuinte perde o direito de reaver o tributo pago indevidamente.

Apesar de o tributo estar eivado do vício da inconstitucionalidade e, portanto, inexigível do contribuinte, a restrição dos efeitos da decisão de inconstitucionalidade, faz com que o tributo inconstitucional seja considerado devido entre a edição de sua norma instituidora até a declaração de sua inconstitucionalidade e indevido apenas após o trânsito em julgado da decisão que o declara inconstitucional.

Se a eficácia da decisão de inconstitucionalidade for fixada pro futuro, isto é, em momento posterior ao trânsito em julgado da decisão de inconstitucionalidade, novamente o tributo pago pelo contribuinte não será restituído e, o que é pior, deverá ser prestado até a data fixada pelo Supremo Tribunal Federal para que a decisão de inconstitucionalidade 
produza efeitos, uma vez que até a data estabelecida, embora inconstitucional, o tributo será devido e deverá ser obrigatoriamente pago.

Os reflexos da restrição dos efeitos ex nunc das decisões que declaram os tributos inconstitucionais são largamente criticados, pois esta limitação impede a restituição do tributo pago indevidamente. "O Estado, enquanto autor da lei inconstitucional, cobrou e arrecadou tributos inconstitucionais, se beneficiando de um ato inconstitucional praticado por ele próprio" (M ARCíLIO, 2008, p. 92).

Ives Gandra Martins (apud MARTINS; MENDES, 2007, p. 205-206) alerta que a fixação de efeitos prospectivos da declaração de inconstitucionalidade "seria como permitir ao assaltante ficar com todo o produto do roubo declarado até o momento em que houve sua condenação, proibido de voltar a roubar as mesmas vítimas depois de condenado".

Comenta, ainda, que para direito tributário a modulação de efeitos poderia gerar:

[...] irresponsabilidade impositiva, fazendo com que exações inconstitucionais, mesmo após o reconhecimento desses vícios por decisão definitiva da Suprema Corte, tenham seus inconstitucionais efeitos perpetuados, em benefício do Estado (M ARTINS; MENDES, 2007, p. 308).

Helenilson Cunha Pontes (2005, p. 80-81), também crítico da restrição dos efeitos da declaração de inconstitucionalidade, afirma que uma vez declarada a inconstitucionalidade do tributo, o correto seria a integral devolução deste, pois foi arrecadado indevidamente pelo Estado. 0 autor complementa que se isto não ocorrer, promove-se "uma tentadora oportunidade para a proliferação de inconstitucionalidades úteis, isto é, exigências de tributos inconstitucionais e não devolvidos após a declaração de tal vício de validade pelo Supremo Tribunal Federal" (PONTES, 2005, p. 80-81).

Tais interpretações doutrinárias possuem grande relevância, reforçando 0 argumento de que criar tributos inconstitucionais pode ser muito rentável para o Estado, pois quando a decisão de inconstitucionalidade tiver seus efeitos restringidos, o Estado não precisará devolver aquilo que recebeu indevidamente, aproveitando-se do produto da arrecadação ilegítima.

No tópico seguinte serão analisados os principais argumentos utilizados para a restrição dos efeitos retroativos das decisões de inconstitucionalidade referente à matéria tributária. 
Razões de Estado como Justificativa para a M odulação dos Efeitos Temporais

Razões de Estado são pseudo-argumentos empregados a fim de assegurar a "supremacia das razões (= interesses) políticas sobre as do direito e/ou da moral. Sendo o Estado um mal perdedor, ele sempre tenta mudar as regras do jogo a seu favor, ainda que 0 faça ignorando-as" (BIM , 2005, p. 42).

As Razões de Estado normalmente são dissimuladas por meio da utilização dos termos razões de governo, razões de poder, razões políticas, interesse público, bem comum, bem geral, interesse nacional e governabilidade (BIM, 2005, p. 43).

0 objetivo principal das Razões de Estado é fazer prevalecer sobre o direito e a moral, interesses políticos. Em face disto, por meio de discursos simuladamente voltados, por exemplo, ao interesse social e ao bem comum manipula-se 0 ordenamento jurídico para que sejam atendidos os interesses exclusivos do Estado.

$\mathrm{Na}$ seara tributária as Razões de Estado se revestem de falácias argumentativas voltadas a "legitimar os interesses meramente arrecadatórios, ignorando os jurídicos que são, em última instância, a fonte do poder que autoriza a tributação" (BIM , 2005, p. 59).

Aplicando-se o que foi visto acerca de Razões de Estado ao tema em questão, diante da possibilidade de o Estado ter que devolver grandes quantias ao contribuinte pelo pagamento do tributo inconstitucional, é que se difundem argumentações, na maioria das vezes, sem fundamentação jurídica, tendentes a evitar que o Estado tenha que restituir aquilo que é de direito do contribuinte.

Para tanto, utiliza-se de alegações voltadas à instabilidade econômica, tais como, grave colapso dos cofres públicos e afronta à governabilidade do país diante da perda de arrecadação, bem como se vale de argumentos que são altamente manipuladores da massa, afirmando-se que a devolução do tributo recolhido indevidamente irá obstar a construção de casas, creches, escolas, postos de saúdes e etc.

A argumentação sem fundamentação jurídica, voltada para justificar a retenção dos tributos indevidos pelo Estado, pode ser constatada nas recentes decisões do Supremo Tribunal Federal acerca da inconstitucionalidade de normas tributárias ${ }^{11}$.

\footnotetext{
${ }^{11}$ As conclusões que serão demonstradas a seguir foram retiradas da análise dos Recursos Extraordinários no․ 556.664, 559.882 e 560.626, os quais declararam a inconstitucionalidade dos dispositivos de lei que dispunham sobre a prescrição e decadência das contribuições para a seguridade social, porém restringiram os efeitos desta decisão sob o argumento de preservar a segurança jurídica.
} 
O que causa estranheza nestas decisões é a forma como a Corte Constitucional brasileira tem modulado a eficácia das pronúncias de inconstitucionalidade.

Ao que se constatou, o Supremo, no tocante a limitação dos efeitos retroativos, não traz fundamentações tendentes a demonstrar que, uma vez aplicado o princípio da nulidade ampla da norma inconstitucional, haveria insegurança jurídica ou mesmo abalo a excepcional interesse social, limitando-se a afirmar que a declaração de inconstitucionalidade geraria grave insegurança jurídica, sem esboçar concretamente como se daria tal insegurança e quais as suas consequências.

Após esta análise, pode-se apurar que o temor dos críticos ${ }^{12}$ à modulação de efeitos quanto à possibilidade dessa exceção se tornar regra no ordenamento jurídico brasileiro, é perfeitamente compreensível.

\section{Conclusão}

Em sede de considerações finais, aponta-se que apesar de muito criticada a restrição dos efeitos temporais das decisões de inconstitucionalidade, seja por sua possível inconstitucionalidade ou ainda por representar uma afronta ao princípio da Supremacia da

Sobre o julgamento que modulou os efeitos da decisão de inconstitucionalidade, convém citar a ementa que trata sobre um dos Recursos Extraordinários acima citados:

PRESCRIÇÃO E DECADÊNCIA TRIBUTÁRIAS. MATÉRIAS RESERVADAS A LEI COMPLEMENTAR.

DISCIPLINA NO CÓDIGO TRIBUTÁRIO NACIONAL. NATUREZA TRIBUTÁRIA DAS CONTRIBUIÇÕES PARA A SEGURIDADE SOCIAL INCONSTITUCIONALIDADE DOS ARTS. 45 E 46 DA LEI 8.212/91 E DO PARÁGRAFO ÚNICO DO ART. 5 DO DECRETO-LEI 1.569/77. RECURSO EXTRAORDINÁRIO NÃO PROVIDO. M ODULAÇÃO DOS EFEITOS DA DECLARAÇÃO DE INCONSTITUCIONALIDADE. I. PRESCRIÇÃO E DECADÊNCIA TRIBUTÁRIAS. RESERVA DE LEI COM PLEMENTAR. As normas relativas à prescrição e à decadência tributárias têm natureza de normas gerais de direito tributário, cuja disciplina é reservada a lei complementar, tanto sob a Constituição pretérita (art. 18, §1ํㅡ, da CF de 1967/69) quanto sob a Constituição atual (art. 146, b, III, da CF de 1988). Interpretação que preserva a força normativa da Constituição, que prevê disciplina homogênea, em âmbito nacional, da prescrição, decadência, obrigação e crédito tributários. Permitir regulação distinta sobre esses temas, pelos diversos entes da federação, implicaria prejuízo à vedação de tratamento desigual entre contribuintes em situação equivalente e à segurança jurídica. II. DISCIPLINA PREVISTA NO CÓDIGO TRIBUTÁRIO NACIONAL. O Código Tributário Nacional (Lei 5.172/1966), promulgado como lei ordinária e recebido como lei complementar pelas Constituições de 1967/69 e 1988, disciplina a prescrição e a decadência tributárias. III. NATUREZA TRIBUTÁRIA DAS CONTRIBUIÇÕES. As contribuições, inclusive as previdenciárias, têm natureza tributária e se submetem ao regime jurídico-tributário previsto na Constituição. Interpretação do art. 149 da CF de 1988. Precedentes. IV. RECURSO EXTRAORDINÁRIO NÃO PROVIDO. Inconstitucionalidade dos arts. 45 e 46 da Lei 8.212/91, por violação do art. 146, III, b, da Constituição de 1988, e do parágrafo único do art. 50 do Decreto-lei 1.569/77, em face do § 10 do art. 18 da Constituição de 1967/69. V. M ODULAÇÃO DOS EFEITOS DA DECISÃO. SEGURANÇA JURÍDICA. São legítimos OS recolhimentos efetuados nos prazos previstos nos arts. 45 e 46 da Lei 8.212/91 e não impugnados antes da data de conclusão deste julgamento. (STF, 2008, p. 65).

${ }^{12}$ Luís Ro berto Barroso, Ives Gandra da Silva M artins e Helenilson Cunha Pontes.

ReVISTA de Direito Púbuco, LondRINA, V, 4, N. 2, P. 59-77, M AIO/AGO. 2009. 
Constituição e aos direitos fundamentais do contribuinte, o fato é que esta existe e possui amparo legal no artigo 27 da lei no 9.868/1999.

Buscando uma solução prática e menos prejudicial ao contribuinte, o caminho mais correto é a exigência de uma fundamentação (motivação) criteriosa e exaustiva para a modulação dos efeitos da decisão de inconstitucionalidade.

Se for alegada insegurança jurídica ao Estado em face da necessidade de se devolver o tributo declarado inconstitucional e, consequentemente, quebra dos cofres públicos, isto deverá ser comprovado empiricamente pelo Supremo Tribunal Federal, através de pareceres de profissionais qualificados, os quais deverão demonstrar por meio de cálculos o efetivo abalo das reservas do Estado e quais áreas de investimento do governo serão atingidas, sob pena de se verificar que todas as alegações utilizadas para restringir a devolução, não passam de pseudo-argumentos utilizados para justificar interesse exclusivo do Estado.

A inobservância de rigorismo na fundamentação dará margem à proliferação de argumentos falaciosos, além do que possibilitará a ocorrência da limitação dos efeitos da decisão de inconstitucionalidade em qualquer situação, fazendo com que o citado dispositivo perca o seu caráter excepcional e passe a tornar-se regra no ordenamento jurídico brasileiro. Assim, inviabiliza-se o direito dos contribuintes em reaver aquilo que pagaram a título de tributo indevido, bem como abala substancialmente a estrutura do Estado Democrático de Direito Tributário e as conquistas de direitos que por meio deste referencial de Estado são possíveis.

\section{Referências}

BALEEIRO, Aliomar. Direito Triutário Brasileiro. 11. ed. Atual. Por M isabel Abreu Machado Derzi. Rio de Janeiro: Forense, 1999.

BARROSO, Luís Roberto. O Controle de Constitucionalidade no Direito Brasileiro. 3.ed. São Paulo: Saraiva, 2008.

BIM, Eduardo Fortunato. A inconstitucionalidade das Razões de Estado e o Poder de Tributar: Violação ao Estado Democrático de Direito. In: XIX CONGRESSO BRASILEIRO DE DIREITO TRIBUTÁRIO, 19., 2005. República e Constituição: preservação de seus princípios. São Paulo: Instituto Geraldo Ataliba - IDEPE, 2005. 
BONAVIDES, Paulo. Curso de Direito Constitucional. 22. ed. São Paulo: Malheiros, 2008.

BRASIL. Supremo Tribunal Federal. Ação Declaratória de Inconstitucionalidade no 652/M A. Relator M inistro Celso de Melo. Brasília, DF, 02 de abril de 1992. Disponível em: বhttp://www.stf.jus.br>. Acesso em: 07 mar 2009.

BRASIL. Superior Tribunal de Justiça. Embargos de Divergência no Recurso Especial no 435.835/SC. Relator M inistro José Delgado. Brasília, DF, 24 de março de 2004. Disponível em «ttp:www.stj.gov.br>. Acesso em: 14 maio 2009.

BRASIL. Superior Tribunal de Justiça. Agravo Regimental no Recurso Especial no 422.704/BA. Voto do Ministro Teori Albino Zavascki. Brasília, DF, 02 de dezembro de 2003. Disponível em «ttp:www.stj.gov.br>. Acesso em: 15 maio 2009.

BRASIL. Supremo Tribunal Federal. Recurso Extraordinário no 61.664/M G. Relator M inistro Aliomar Baleeiro. Brasília, DF, 21 de maio de 1968. Disponível em: «ttp:www. stf.jus.br>. Acesso em: 03 maio 2009

BRASIL. Supremo Tribunal Federal. Recurso Extraordinário no 556.664. Relator M inistro Gilmar M endes. Brasília, DF, 12 de junho de 2008. Disponível em: «ttp:www.stf.jus.br>. Acesso em: 01 maio 2009.

CARRAZZA, Roque Antonio. Curso de Direito Constitucional Tributário. 23. ed. São Paulo: Malheiros, 2007.

FERRARI, Regina M aria Macedo Nery. Efeitos da declaração de inconstitucionalidade. 5.ed. São Paulo: Revista dos Tribunais, 2004.

GRECO, M arco Aurélio; PONTES, Helenilson Cunha Pontes. Inconstitucionalidade da Lei Tributária - Repetição de Indébito. São Paulo: Dialética, 2002.

M ARCILIO, Carlos Flávio Venâncio. Declaração de Inconstitucionalidade no controle concentrado. Revista Tributária e de Finanças Públicas. a. 2008, n. 79.

M ARTINS, Ives Gandra da Silva. Arguição de Descumprimento de Preceito Fundamental: Análises à luz da Lei 9.882/99. São Paulo: Atlas, 2001.

- MENDES, Gilmar Ferreira. Controle Concentrado de Constitucionalidade: Comentários à Lei n. 9.868, de 10-11-1999. 2.ed. São Paulo: Saraiva, 2007.

M ORAES, Alexandre de. Direito Constitucional. 23. ed. São Paulo: Atlas, 2008. 
PALU, Oswaldo Luiz. Controle de Constitucionalidade: Conceitos, sistemas e efeitos. 2. ed. São Paulo: Revista dos Tribunais, 2001.

PAULSEN, Leandro. Direito Tributário: Constituição e Código Tributário à Luz da Doutrina e da Jurisprudência. 10.ed. Porto Alegre: Livraria do Advogado, ESM AFE, 2008.

PIM ENTA, Paulo Roberto Lyrio. Efeitos da Decisão de Inconstitucionalidade em Direito Tributário. São Paulo: Dialética, 2002.

PONTES, Helenilson Cunha. Coisa julgada tributária e inconstitucionalidade. São Paulo: Dialética, 2005.

TORRES, Ricardo Lobo. Limitações ao poder impositivo e segurança jurídica - Pesquisas Tributárias. Revista dos Tribunais. a 2005. n. 11. 